\title{
In-vitro Cytotoxic Activity of E. coli Outer Membrane Vesicles (OMVs) Against Breast Cancer (MCF-7) Cell Line
}

\author{
Mahmood Abed Hamzah ${ }^{1}$, Ali Husain Alwan ${ }^{2}$, Suzan Saadi Hussain ${ }^{2}$ \\ ${ }^{1}$ PhD Student, ${ }^{2}$ Prof., Department of Biology, College of Science, Al-Mustansiriyah University, Iraq
}

\begin{abstract}
Twenty-five samples of urine were collected from patients suffering Urinary Tract Infection (UTI) from hospital in Baghdad,twenty-two bacterial isolated (88\%) were identified. From our result showed the E. coli number 5 is the best bacterial virulence factor for producing OMV, Tumor cells $\left(1 \times 10^{4}-1 \times 10^{6}\right.$ cells $\left./ \mathrm{ml}\right)$ have been grown in 96 flat well micro-title plates, with a final volume of 200 cells per well. The microplate was gently shackled and covered by sterilized parafilm then incubation of the plates at $37 \mathrm{C}^{\circ}, 5 \% \mathrm{CO}_{2}$ for $24 \mathrm{hrs}$. Two folded serial dilutions of the desired compound $(12.5,25,50,100,200,400 \mu \mathrm{g} / \mathrm{mL})$ were added to the wells after incubation. Triplicates were used per each concentration as well as controls (serum-free medium treated cells). Plates were incubated for specified exposure time ( 24 hours) at $37 \mathrm{C}^{\circ}, 5$ percent $\mathrm{CO} 2$. Applied $10 \mu$ liters of MTT solution to each well after exposure. The absorbance was determined by a wavelength of $575 \mathrm{~nm}$ using an ELISA reader. Statistical analysis was performed on the optical density data to calculate the compound concentration required to cause a 50 percent reduction in cell viability for each cell line. The rate of cell growth inhibition (the cytotoxicity percentage) was calculated and plot of $\%$ cytotoxicity against sample concentrations assisted to calculate the concentration which exhibited 50\% cytotoxicity $\left(\mathrm{IC}_{50}\right)$. Calculate: cell number: determine cells per milliliter.
\end{abstract}

Keywords: Cytotoxic Activity; E. coli; outer Membrane Vesicles (OMVs); breast cancer (MCF-7).

\section{Introduction}

Outer membranes vesicles (OMVs) can to transfer biological molecules to host cells and their development among gram-negative bacteria is intended. Apart from their role in the communication of bacteria, virulence factors are transferred to the host for cargoes to OMVs to boost bacterial survival ${ }^{(\mathbf{1})}$.

Outer membranes vesicles have properties which permit the transmission of DNA fragments, autolysins, cytotoxins, virulence factors, and various other biomolecules to be mediated by them and their secretion allows bacteria to interact with and within the species

\section{Corresponding Author:}

Mahmood Abed Hamzah

PhD Student, Department of Biology, College of

Science, Al-Mustansiriyah University, Iraq

e-mail: bellnancy651@gmail.com and also strengthens their contact with the host. OMVs were recognized for their role in nutrient procurement, stress reactions and toxin transmission, adherence to and virulence factors in avoiding host defense systems among the prominent roles in various pathological and physiological ${ }^{(2,3)}$.

Cancer is an uncontrolled cellular development and spreading disease, where cells do not respond to the normal controls and cause the tumor to grow and to metastasize $^{(4) .}$ However, chemotherapy does not target drugs directly in cancer sites, which ensures that healthy cells are susceptible to adverse reactions. Also because of its fast removal and nonspecific distribution, a large dose is needed ${ }^{(\mathbf{5}) \cdot}$ The goal of nanomedicine is to identify cost-effective molecules with high cell specificities and susceptibility ${ }^{(\mathbf{6})}$.

Cancers' immunotherapy may be categorized as immunothérapic therapies with the goal of utilizing innate or adaptive immunity in oncology ${ }^{(7)}$. 
Nevertheless, the successful treatment and eradication of cancer tumors have been avoidable due to inadequate induction of immune responses using conventional vaccination approaches, despite the tremendous potential of cancer vaccines ${ }^{(\mathbf{8}) \cdot}$. It highlights the need for new vaccine approaches, in which tumor antigens and APC adjuvants are administered effectively and with a good enough immune response to kill tumor cells. Over the past three decades, nanoparticles have been intensively studied as a delivery method of modern chemotherapy over firm tumors $\mathbf{( 9 , 1 0 )}$.

\section{Material and Method}

Method for preparation of outer membrane vesicles (OMV): Overnight on lysogeny broth, bacterial cells were cultivated with shaking at $37{ }^{\circ} \mathrm{C}$ (150rp.m.) until the OD600 reached 1.5 (1 percent tryptone, 0 percent yeast extract, 1 percent $\mathrm{NaCl}, 7.0 \mathrm{pH})$. At 5000rpm twice for $20 \mathrm{~min}$, at $4{ }^{\circ} \mathrm{C}$, the cultivated cells were pelleted. The supernatant was filtered with a $0.45 \mu \mathrm{m}$ pore filter and then applied supernatant to cold absolute ethanol at $4^{\circ} \mathrm{C}$ (twice the volume of supernatant), which lasted 24 hours. This resulted in rough precipitation isolation. The precipitation was dissolved in deionized water and dialysed using a 14000D tubular dialyzis membrane for 24-48 hours with Spectra/Por molecular pore.At $15000 \mathrm{rpm}$ twice for $20 \mathrm{~min}$, at $4^{\circ} \mathrm{C}$, the precept cells were pelleted by using high speed centrifuge. A filter with a pore size of $0,22 \mu \mathrm{m}$ and the OMV pellet were filtered again into water and held at $-80{ }^{\circ} \mathrm{C}$ for further experiments.

Gel chromatography purification: The Pharmacia Fine Chemicals Company has prepared Sephadex G-200 as recommended. A quantity of Sephadex G-200 has been suspended, degassed, and wrapped in $0.1 \mathrm{M}$ Tris$\mathrm{HCl}$ buffer $\mathrm{pH} 8(1.5 \times 80 \mathrm{~cm})$, the gel has been preserved for 72 hours. Then balanced with the same buffer at room temperatures for swelling. Elution was done at a flow rate of $30 \mathrm{ml} / \mathrm{hr}$ and the same control buffer was used. At $280 \mathrm{~nm}$, absorbance was measured for each fraction.

In-vitro cell line design: From the National Center for Cell Sciences (NCCS) Pune, breast cancer MCF-7 cell lines were obtained. The cells were maintained in a humidified atmosphere of $50 \mathrm{lg} / \mathrm{ml} \mathrm{CO} 2$ at $37 \mathrm{LC}$ in Limited Essential Media supplemented with 10 percent FBS, penicillin $(100 \mathrm{U} / \mathrm{ml})$, and streptomycin $(100 \mathrm{lg} /$ $\mathrm{ml})$.

\section{Cell Preparation:}

1. The medium EMEM containing: $10 \%$ bovine serum fetal, $1 \mathrm{mM}$ pyruvate, 100 units of penicillin, and $100 \mu \mathrm{g} / \mathrm{ml}$ streptomycin (EPEM full solution), $1 \mathrm{X}$ non-essential amino acids. It was used to treat the following compounds.

2. When $90 \%$ confluence was reached at a dilution of 1:4, MCF7 cells were divided. Using several of cells at passage $=10$.

3. Tripsinisation of MCF7 cells, diluting to EMEM, was conducted on a complete medium and cell density. In complete EMEM, cells have been diluted into 7.5 to 104 cells $/ \mathrm{ml}$.

4. In each 96-well-microplate well the cell suspension $(100 \mu \mathrm{l})$ has been added to achieve 7.500cells/well (7.500cells/well- recommended planting density).

5. Overnight the cells have been incubated at $37{ }^{\circ} \mathrm{C}$ with $5 \% \mathrm{CO} 2$.

\section{Cell Line Maintenance ${ }^{(11) .}$}

The following protocol was performed when the cells in the vessel formed confluent monolayer:

The cell sheet was washed with PBS.

A. The growth medium was drained.

B. The cell has been given two to three $\mathrm{ml}$ of tetraacetic ethylene diamine (EDTA) solution. The ship was transformed into a soft rocking cover for the monolayer. The vessel allowed incubation of the cells at $37^{\circ} \mathrm{C}$ for between 1 to 2 minutes.

C. The cells were dispersed from the wedding surface into the pipetting medium for production. This medium was applied to the Fresh RPMI medium (15-20 mL).

Incubated at $37{ }^{\circ} \mathrm{C}$ and distributed in $5 \%$ of the $\mathrm{CO} 2$ incubator D- cells were redistributed in cultivated vessels, flasks or plates whatever is required.

By using the hemocytometer and using the formula, cell concentration was determined by counting the cells:

Total Cell Count $/ \mathrm{ml}$ : Cell count $\mathrm{x}$ dilution factor (sample volume) $\times 10^{4}$

MTT Protocol: The cytotoxic effect of different compounds isolated from $\mathrm{Ag}$ Nanoparticles, OMVs, and combination of OMVs and Ag Nanoparticles was performed using MTT ready to use the kit.Tumor cells $\left(1 \times 10^{4}-1 \times 10^{6}\right.$ cells $\left./ \mathrm{ml}\right)$ have been grown in 96 flat well 
micro-title plates, with a final volume of 200 cells per well. The microplate was gently shackled and covered by sterilized parafilm. Incubation of the plates at $37 \mathrm{C}^{\circ}, 5$ $\% \mathrm{CO}_{2}$ for $24 \mathrm{hrs}$. then two folded serial dilutions of the desired compound $(12.5,25,50,100,200,400 \mu \mathrm{g} / \mathrm{mL})$ were added to the wells after incubation. Triplicates were used per each concentration as well as controls (serumfree medium treated cells). Plates were incubated for specified exposure time ( 24 hours) at $37 \mathrm{C}^{\circ}, 5$ percent $\mathrm{CO} 2.10 \mu$ liters of MTT solution was applied to each well after exposure. Plates were further incubated for 4 hours at $37^{\circ} \mathrm{C}, 5 \% \mathrm{CO}$. Carefully removed media and added $100 \mu 1$ of solubilization solution per well for 5 minutes. The absorbance was determined by a wavelength of $575 \mathrm{~nm}$ using an ELISA reader. Statistical analysis was performed on the optical density data to calculate the compound concentration required to cause a 50 percent reduction in cell viability for each cell line. The rate of cell growth inhibition (the cytotoxicity percentage) was calculated as the following equation:-

$\%$ Cell viability $=$ (Absorbance of treated cell/ Absorbance of the non-treated cell) $\mathrm{x} 100$.

$\%$ Cytotoxicity $=100-$ cell viability.

IC50 (Dose concentration that inhibited cell growth by $50 \%$ )values were calculated by the linear and logarithmic correlation equation.

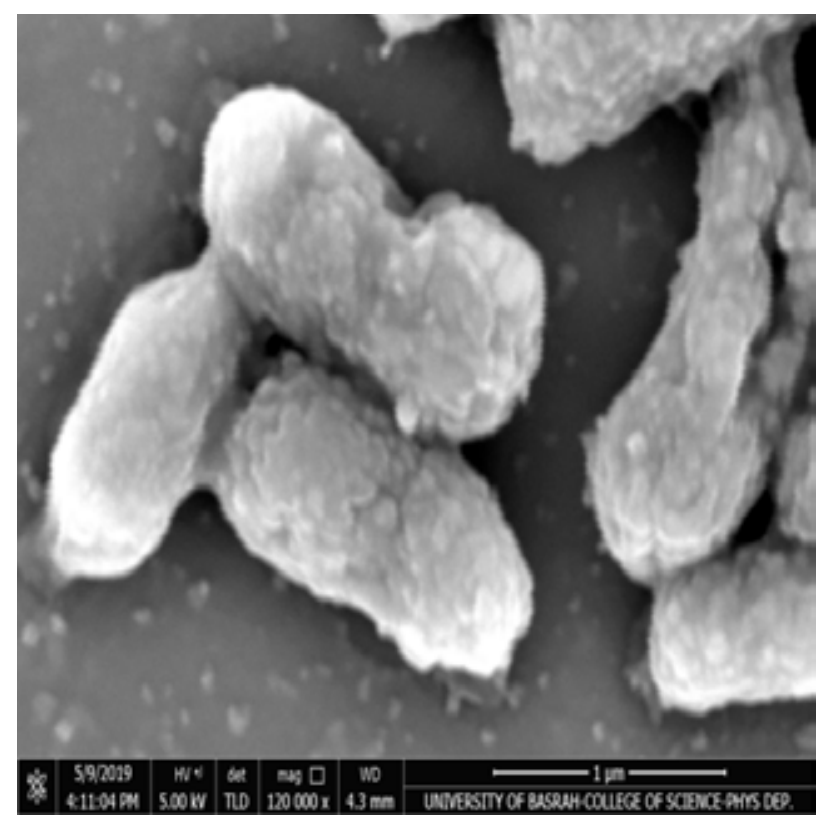

A plot of $\%$ cytotoxicity against sample concentrations assisted to calculate the concentration which exhibited $50 \%$ cytotoxicity $\left(\mathrm{IC}_{50}\right)$.

Calculate cell number: determine cells per milliliter by the following calculation:

Cells $/ \mathbf{m L}=$ average count each square $\times$ dilution factor $\times 10^{4}$ total cells $=$ Cells $/ \mathrm{mL} \times$ total unique volume of cell suspension from which sample was occupied. The number $10^{4}$ is the volume correction factor for the hemocytometer: each square is $1 \times 1 \mathrm{~mm}$ also the depth is $0.1 \mathrm{~mm}$.

\section{Results and Discussion}

The results of screening the highest and best bacterial virulence factors isolates for producing OMV showed that isolate number five 5 is the best for the ability to produce OMV Figure (3-6) and (3-7) with an average diameter of $61.08-103.2 \mathrm{~nm}$.

Isolation OMV: The results of screening the highest and best bacterial virulence factors isolates for producing OMV showed that isolate number five 5 is the best for the ability to produce OMV Figure (1\&2) with an average diameter of $61.08-103.2 \mathrm{~nm}$.

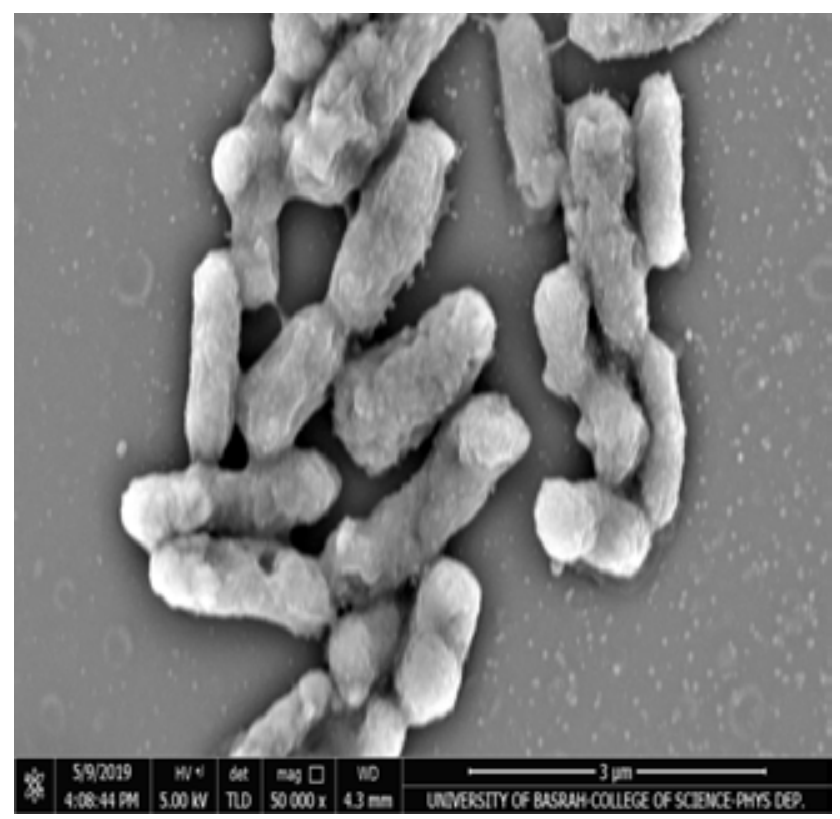



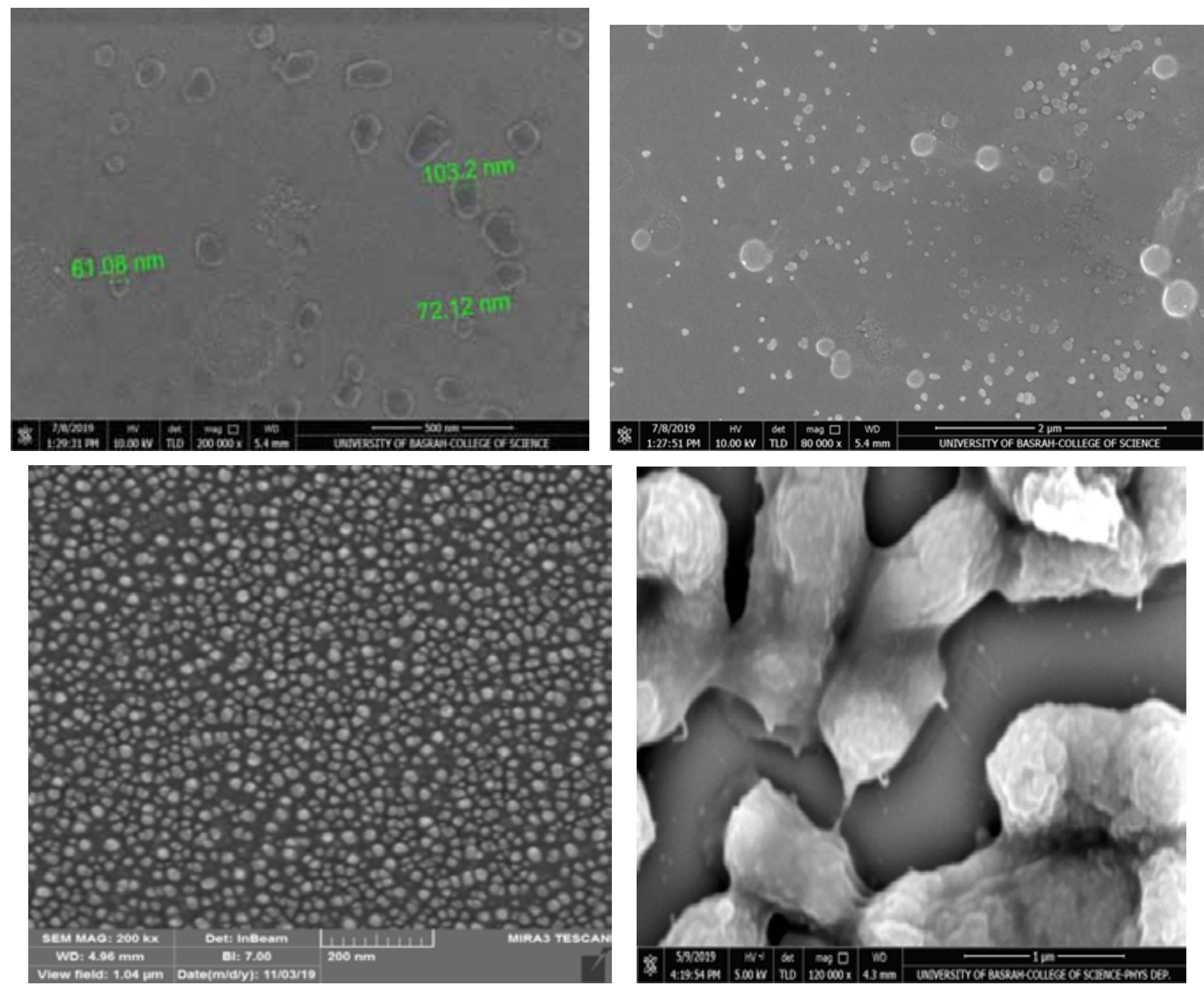

Figure (1): SEM shows the ability of isolate no. 5 to produce outer membrane vesicles (OMV)
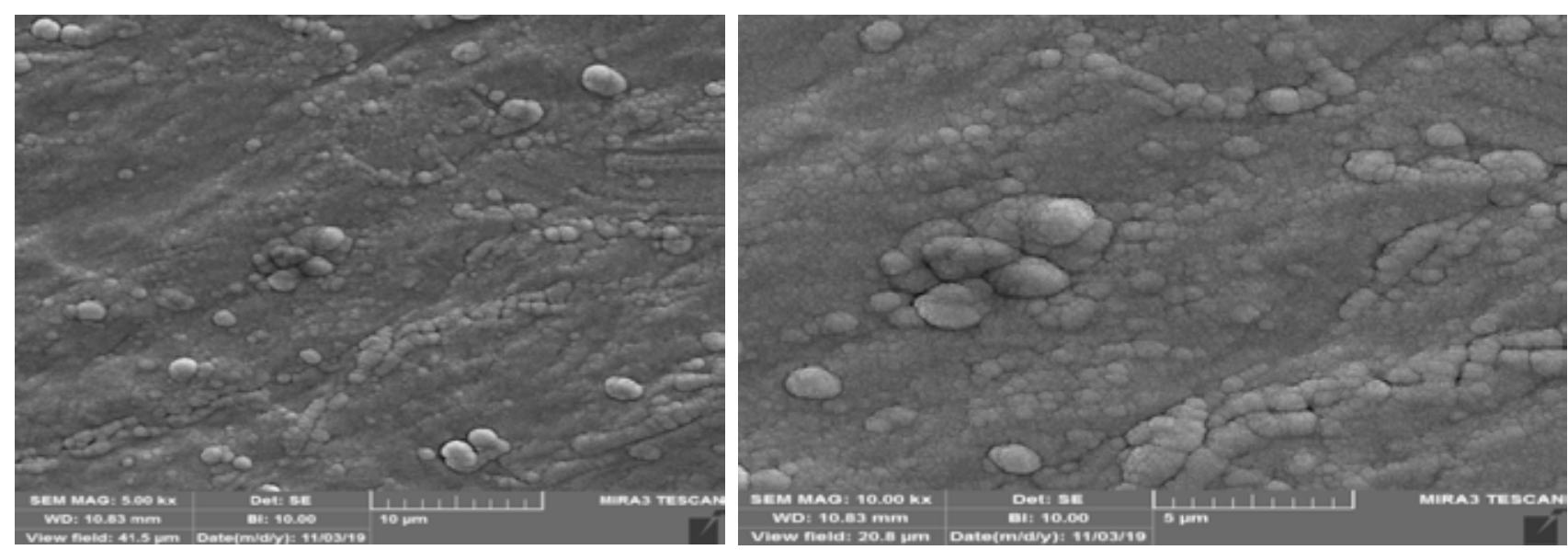

Figure (2): SEM shows the ability of isolate no. 5 to produce outer membrane vesicles(OMVs) by gel filtration chromatography method 
Kim et al . (2017) have shown both E. coli wild type and mutant bacteria-derived OMVs have nanodimensional lipid-bilayer vesicular structures, both E.coli of which showed with an average diameter of $38.6 \pm 3.6$ and $38.7 \pm 4.2 \mathrm{~nm}$ along with the wild-type $E$. coli, OMVs had a higher range of production. OMV E.coli, giving an extra advantage of OMVs, as naturally generated OMVs have low productivity issues ${ }^{(\mathbf{1 2})}$.

Behrouzi et al., (2018) showed that the extracted OMV was 20-75 $\mathrm{nm}$ from the disease strain, whereas the
OMV was 45-270 nm from the non-pathogenic strain ${ }^{(13)}$. Rolhion et al., (2005) showed that the pathogenic strain may produce significantly smaller vesicles than the nonpathogenic strain ${ }^{(\mathbf{1 4})}$, they demonstrated that adequateinvasivity Escherichia coli strain LF82 can invade the cultivated intestinal epithelial cells recovered from chronic injury of a patient with Crohn9s disease. Anand and Chaudhuri., (2016) have shown that both pathogenic and nonpathogenic bacteria are made of outer membrane vesicles (OMVs) $(50-250 \mathrm{~nm}$ in diameter) as the canonical result of secretion ${ }^{(15)}$.

Table (1): Percentage of cell viability MCF-7cancer cell line to E.coli Outer Membrane Vesicles (OMV) at different concentrations

\begin{tabular}{|c|c|c|c|c|c|}
\hline \multirow{2}{*}{ Row Stats } & \multirow{2}{*}{ X Title } & \multicolumn{2}{|c|}{ A } & \multicolumn{2}{|c|}{ B } \\
\cline { 2 - 6 } & & \multicolumn{2}{|c|}{ MCF-7 } & \multicolumn{3}{c|}{ WRL68 } \\
\cline { 2 - 6 } & $\mathbf{N}$ & Mean \pm SD & Nean \pm SD & 3 \\
\hline 1 & 400.000 & $44.414 \pm 5.048$ & 3 & $76.196 \pm 3.855$ & 3 \\
\hline 2 & 200.000 & $44.421 \pm 9.090$ & 3 & $95.957 \pm 2.609$ & 3 \\
\hline 3 & 100.000 & $54.553 \pm 1.860$ & 3 & $95.596 \pm 2.100$ & 3 \\
\hline 4 & 50.000 & $59.568 \pm 0.821$ & 3 & $95.216 \pm 0.821$ & 3 \\
\hline 5 & 25.000 & $72.801 \pm 0.904$ & 3 & $95.949 \pm 1.028$ & 3 \\
\hline
\end{tabular}

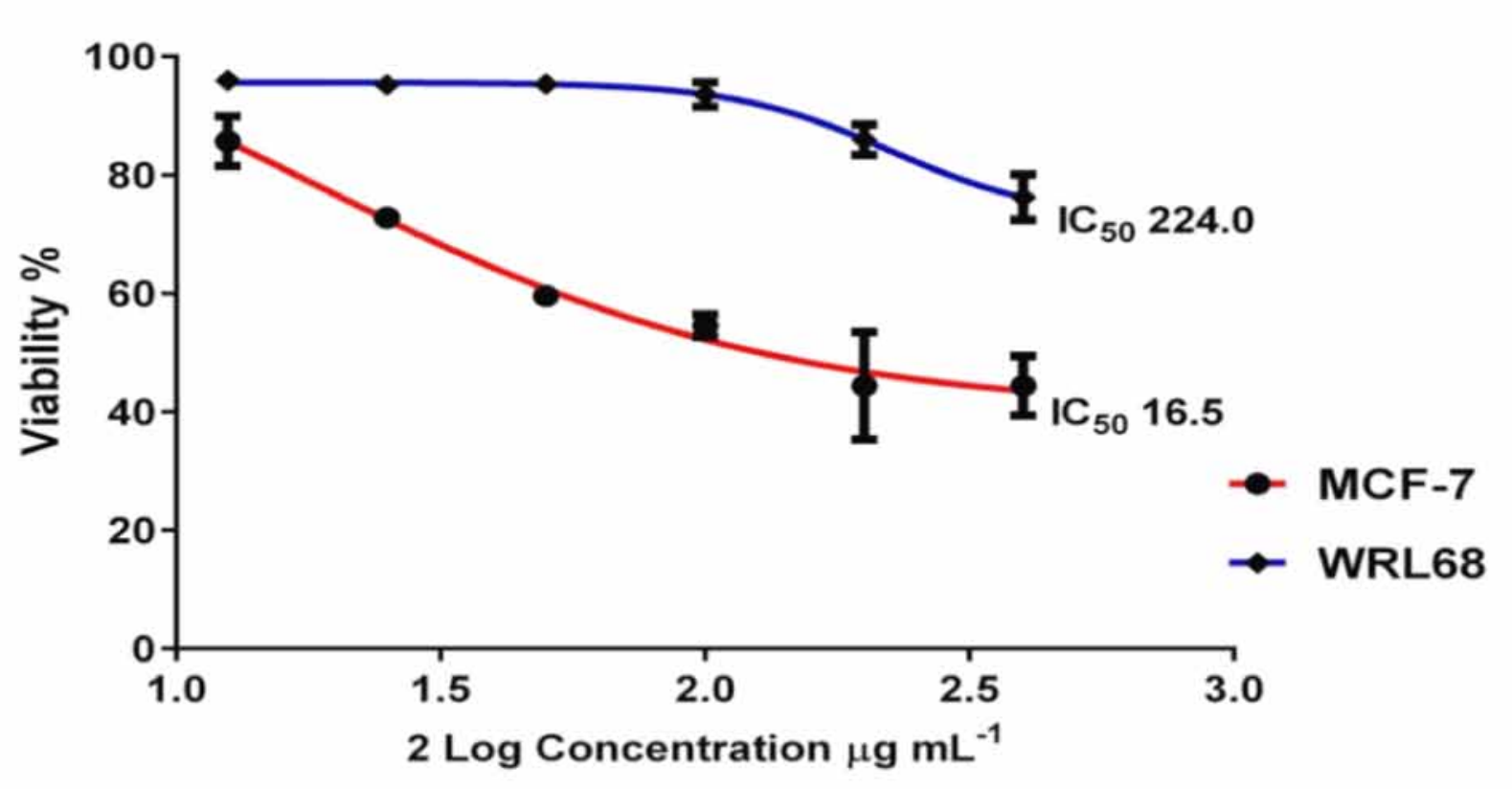

Figure (3): Shows Cytotoxic activity of isolate no.5 outer membrane vesicles against Breast cancer (MCF-7) using MTT test after $24 \mathrm{~h}$. and 37o C. 
The IC50 which is the half- maximal inhibitory concentration for cell growth constructing adose response curve was measured. outer membrane vesicles showed IC50 $16.5 \mathrm{Mg} / \mathrm{ml}$ compared with WRL68 showed IC50 $224 \mu \mathrm{g} / \mathrm{ml}$.

At a concentration of $12.5 \mathrm{Mg} / \mathrm{ml}, 85.687 \%$ cell viability was observed after treatment with OMVs. However, cell viability reached to $44.414 \%$ using $400 \mathrm{Mg} / \mathrm{ml}$ concentration with OMVs.

Zhang et al.,2019 demonstrated in many studies the propensity for immunization with OMV components can be caused by $\mathrm{OMV}^{(\mathbf{1 6})}$. Toxins can act as adhesives for OMVs and thus enable vesicles to enter cells via

the endocytic pathway through a receptor. The host cell input could also be supplemented by common components of vesicles, such as outer membrane protein A (OmpA), this adhesive is fully activated in the OMV membrane rather than as a mixture of purified vesicle components, when it is presented. OMVs are sized (20$200 \mathrm{~nm}$ ) and can present a variety of surface antigens in a native conformed that enables them to be introduced to lymph vessels and taken up by APCs. The natural features of OMVs like immunogenicity, the ability to act as self-adjuvants, and the ability of immune cells also make them appealing for use as pathogenic bacterial vaccinations.

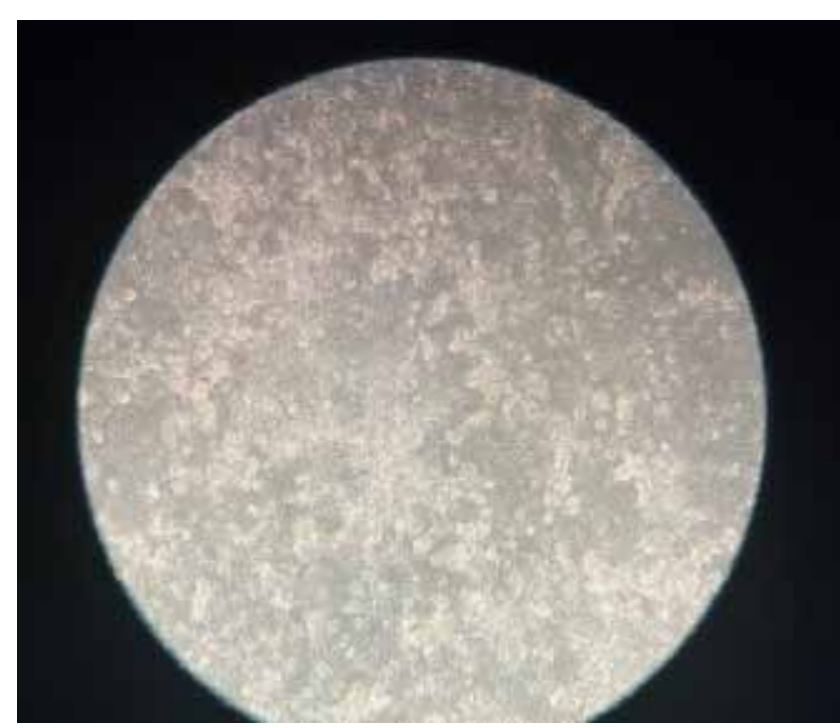

(a)

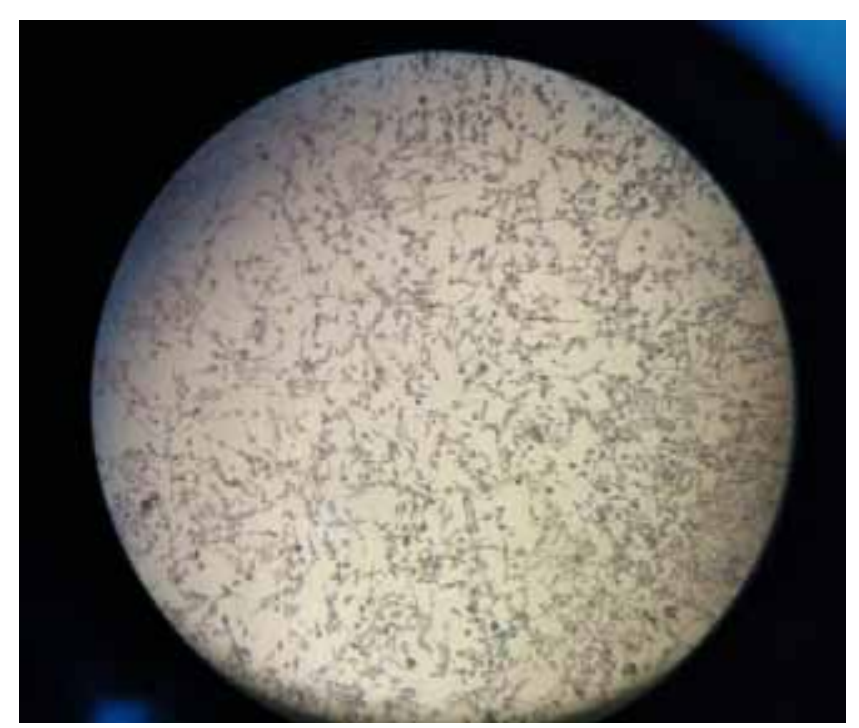

(b)

Figure (4): Showed the (a) untreated MCF-7 tumors cell mass showing the proliferating tumor cell (b) treated MCF-7 tumors cell showing massive area of MCF-7

Bélteky et al., (2019) showed thatcell viability assays on human A549 adenocarcinoma as well as on non-cancerous MRC-5 fibroblast cells ${ }^{(17)}$. The aggregation dependent toxicity of both AgNP samples was investigated at nanoparticle concentrations corresponding to the respective cell line-specific IC50 (A549: IC50AgNPC $=72.2 \pm 4.1 \mathrm{ppm} ;$ IC50AgNPGT $=63.1 \pm 3.8 \mathrm{ppm} ; \mathrm{MRC}-5:$ IC50AgNPC $=17.6 \pm 3.0 \mathrm{ppm}$; IC50AgNPGT $=1.3 \pm 0.2 \mathrm{ppm}$ ).

Nazir et al., (2011) reported that for both cell lines Human cancer cell lines HT144 (malignant melanoma of skin) and H157 (squamous cell lung carcinoma) against silver nanoparticles, cytotoxic activity was observed $^{(\mathbf{1 8}) \cdot}$ The $50 \%$ inhibition dose of growth (ID50) at $3.6 \mu \mathrm{M}$ was observed. It was further observed that the nanoparticles had an immediate effect as observed under the Inverted Light Microscope following treatment with silver nanoparticles. There was a clear morphological change in cells under the microscope when they lost their attached nature and got rounded.

\section{Conclusion}

In vitro experiment showed the OMV optimum cytotoxic activity against breast cancer(MCF- 7) cell line by MTT method, the result showed $44.414 \%$ cell viability. 


\section{Conflict of Interest: Non}

Source of Findings: Self-findings.

Ethical Clearance: Non

\section{References}

1. 1 hattopadhyay, M. K., \& Jaganandham, M. V. Vesicles-mediated resistance to antibiotics in bacteria. Front. Microbiol.2015. 6:758.

2. Biller, S. J., Schubotz, F., Roggensack, S. E., Thompson, A. W., Summons, R. E., \& Chisholm, S. W. Bacterial vesicles in marine ecosystems. science, 2014.343(6167), 183-186.

3. Fulsundar, S., Harms, K., Flaten, G. E., Johnsen, P. J., Chopade, B. A., \& Nielsen, K. M.Gene transfer potential of outer membrane vesicles of Acinetobacter baylyi and effects of stress on vesiculation. Appl. Environ. Microbiol.,2014. 80(11), 3469-3483.

4. Jurj, A., Braicu, C., Pop, L. A., Tomuleasa, C., Gherman, C. D., \& Berindan-Neagoe, I. The new era of nanotechnology, an alternative to change cancer treatment. Drug design, development and therapy, 2017.11, 2871.

5. Rai, M., Kon, K., Ingle, A., Duran, N., Galdiero, S., \& Galdiero, M.Broad-spectrum bioactivities of silver nanoparticles: the emerging trends and future prospects. Applied microbiology and biotechnology, 2014.98(5), 1951-1961.

6. Riehemann, K., Schneider, S. W., Luger, T. A., Godin, B., Ferrari, M., \& Fuchs, H.Nanomedicinechallenge and perspectives. Angewandte Chemie International Edition, 2009.48(5), 872-897.

7. Adams, J. L., Smothers, J., Srinivasan, R., \& Hoos, A. Big opportunities for small molecules in immuno-oncology. Nature reviews Drug discovery, 2015. 14(9), 603-622.

8. Rosenberg, S. A., Yang, J. C., \& Restifo, N. P. Cancer immunotherapy: moving beyond current vaccines. Nature medicine, 2004.10(9), 909-915.

9. Wang, X., Li, S., Shi, Y., Chuan, X., Li, J., Zhong, T., ... \& Zhang, Q. The development of site-specific drug delivery nanocarriers based on receptor mediation. Journal of controlled release, 2014.193, 139-153.
10. He, Z., Schulz, A., Wan, X., Seitz, J., Bludau, H., Alakhova, D. Y. \& Kabanov, A. V. Poly (2-oxazoline) based micelles with high capacity for 3rd generation taxoids: Preparation, in vitro and in vivo evaluation. Journal of controlled release, 2015 . 208, 67-75.

11. Al-Shammari A.; Yaseen Y.; Alwan, M. Establishment and characterization of AMN3 first murine mammary adenocarcinoma transplantable tumor line in Iraq. Journal of Iraqi Cancer.2008.1(2):1.

12. Kim, O. Y., Park, H. T., Dinh, N. T. H., Choi, S. J., Lee, J., Kim, J. H., ... \& Gho, Y. S. Bacterial outer membrane vesicles suppress tumor by interferon- $\gamma$-mediated antitumor response. Nature communications, 2017.8(1), 1-9.

13. Behrouzi, A., Vaziri, F., Rad, F. R., Amanzadeh, A., Fateh, A., Moshiri, A., \& Siadat, S. D.Comparative study of pathogenic and non-pathogenic Escherichia coli outer membrane vesicles and prediction of host-interactions with TLR signaling pathways. BMC research notes, 2018.11(1), 539.

14. Rolhion, N., Barnich, N., Claret, L., \& DarfeuilleMichaud, A. Strong decrease in invasive ability and outer membrane vesicle release in Crohn's disease-associated adherent-invasive Escherichia coli strain LF82 with the yfgL gene deleted. Journal of bacteriology,2005. 187(7), 2286-2296.

15. Anand, D., \& Chaudhuri, A. Bacterial outer membrane vesicles: New insights and applications. Molecular membrane biology, 2016.33(6-8), 125137.

16. Zhang, Y., Fang, Z., Li, R., Huang, X., \& Liu, Q. Design of Outer Membrane Vesicles as Cancer Vaccines: A New Toolkit for Cancer Therapy. Cancers, 2019.11(9), 1314.

17. Bélteky, P., Rónavári, A., Igaz, N., Szerencsés, B., Tóth, I. Y., Pfeiffer, I. \& Kónya, Z. Silver nanoparticles: Aggregation behavior in biorelevant conditions and its impact on biological activity. International journal of nanomedicine, 2019.14, 667.

18. Nazir, S., Hussain, T., Iqbal Md, M. K., Muazzam, A. G., \& Ismail, J. M. Novel and cost-effective green synthesis of silver nano particles and their in vivo antitumor properties against human cancer cell lines. Biosci Tech,2011. 2(6), 425-430. 